\section{Recollection of a rare epiphytic orchid Taeniophyllum filiforme J.J. Sm. (Orchidaceae) after a lapse of 135 years from South Andaman Islands, India}

\author{
K. Karthigeyan ${ }^{1}$, R. Sumathi ${ }^{2} \&$ J. Jayanthi ${ }^{3}$ \\ ${ }^{1}$ Central National Herbarium, Botanical Survey of India, \\ A.J.C.B. Indian Botanic Garden, P.O. Botanic Garden, Howrah, \\ West Bengal 711103, India \\ ${ }^{2}$ Foundation for Revitalisation of Local Health Traditions \\ (FRLHT), 74/2, Jarakabande Kaval, Attur Post (via Yelahanka), \\ Bengaluru Karnataka 560064, India \\ ${ }^{3}$ Botanical Survey of India, Western Regional Centre \\ 7 - Koregaon Road, Pune, Maharashtra 411001, India \\ Email: ${ }^{1}$ karthigeyan.murthy@gmail.com (corresponding author), \\ ${ }^{2}$ sumathi.ramamurthy@gmail.com, ${ }^{3}$ jayanthi.bsi@gmail.com
}

The genus Taeniophyllum Blume is a group of small monopodial, leafless epiphytic orchid with a minute central stem. The generic name denotes the tapewormlike long roots. The roots are green, contain chlorophyll that performs photosynthesis and the true leaves are reduced to tiny scales covering the stem. It belongs to the Vandeae group of the tribe Epidendroideae of the family Orchidaceae (Seidenfaden 1988; Seidenfaden\& Wood 1992; Comber 2001; Mabberley 2008). So far 170 species have been reported which are distributed from tropical Africa, India and Sri Lanka, East and

Date of publication (online): 26 December 2012

Date of publication (print): 26 December 2012

ISSN 0974-7907 (online) | 0974-7893 (print)

Editor: N.P. Balakrishnan

\section{Manuscript details:}

Ms \# 02851

Received 29 June 2011

Final received 25 July 2012

Finally accepted 23 October 2012

Citation: Karthigeyan, K., R. Sumathi \& J. Jayanthi (2012). Recollection of a rare epiphytic orchid Taeniophyllum filiforme J.J. Sm. (Orchidaceae) after a lapse of 135 years from South Andaman Islands, India. Journal of Threatened Taxa 4(15): 3433-3435.

Copyright: (C) K. Karthigeyan, R. Sumathi \& J. Jayanthi 2012. Creative Commons Attribution 3.0 Unported License. JoTT allows unrestricted use of this article in any medium for non-profit purposes, reproduction and distribution by providing adequate credit to the authors and the source of publication.

Acknowledgements: The authors are thankful to Dr. M. Sanjappa, ExDirector, Dr. H.J. Chowdhery, Addl. Director (Retd.) and Dr. P.G. Diwakar Joint Director, Botanical Survey of India for encouragement and facilities. They also thank Dr. D. Narasimhan and Dr. C. Livingstone, Madras Christian College, Tambaram for encouragement.

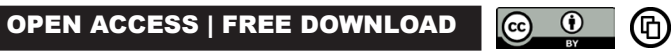

Southeast Asia, to Australia and the Pacific Islands (Comber 1990; Mabberley 2008). Nine species are reported from India including four endemics (Kumar \& Manilal 1994). Three species are known to occur in the Andaman Islands, namely, the endemic Taeniophyllum andamanicum N.P. Balakr. \& Bhargava, T. filiforme J. J. Sm. and T. insulare Seidenf. (Rao 1986; Mathew 1998; Pandey \& Diwakar 2008).

The occurrence of Taeniophyllum filiforme in the Andaman Islands was first known when Dr. Lars Johnson identified this species from the collection made by Kurz from the South Andamans in 1867 deposited in Kew. After that there was no record of this extremely rare species from the Andaman Islands and the occurrence of this interesting species remained a mystery. While inventorising the floristic diversity of Rutland Island during the year 2002 this flimsy orchid was found growing on the branches of Pterocarpus dalbergioides Roxb. ex DC. and only a few individuals were observed. On scrutiny of literature it was identified as Taeniophyllum filiforme, an extremely rare orchid in the inland forests of the Andaman Islands. The present collection of this tiny orchid from the tropical forests of South Andaman is a recollection after a lapse of 135 years. Since this orchid is leafless, only the green roots appear on the bark of trees, the pale yellow flowers are very short lived and this could be one of the reasons for being unnoticed over many years. Taeniophyllum filiforme is also listed in the CITES Appendix II by the World Conservation Monitoring Centre (UNEP WCMC 2003). Detailed description and illustration along with notes on its ecology and distribution are provided for easy identification of this rare orchid.

Taeniophyllum Blume, Bijdr. 355. 1825; Hook.f., Flora British India 6: 76. 1890. Lectotype: T. obtusum Blume.

Taeniophyllum filiforme J.J. Sm. Bull. Inst. Bot. Buitenzorg 7: 4. 1900; Seidenf. in Opera Bot. 95: 21. 1988; J.B. Comber in Orchids Java 360. 1990; Seidenf. \& J.J. Wood in Orchids Penin. Malaysia \& Singapore 579. 1992; J.B. Comber in Orchids Sumatra 980. 2001. T. macrorrhizum Ridl. in Fl. Malay Penin. 4: 176. 1924. (Fig. 1; Images 1\&2).

Epiphytes. Roots wiry, more or less flat, green. Inflorescence arising from the base, 1-2 flowered, 


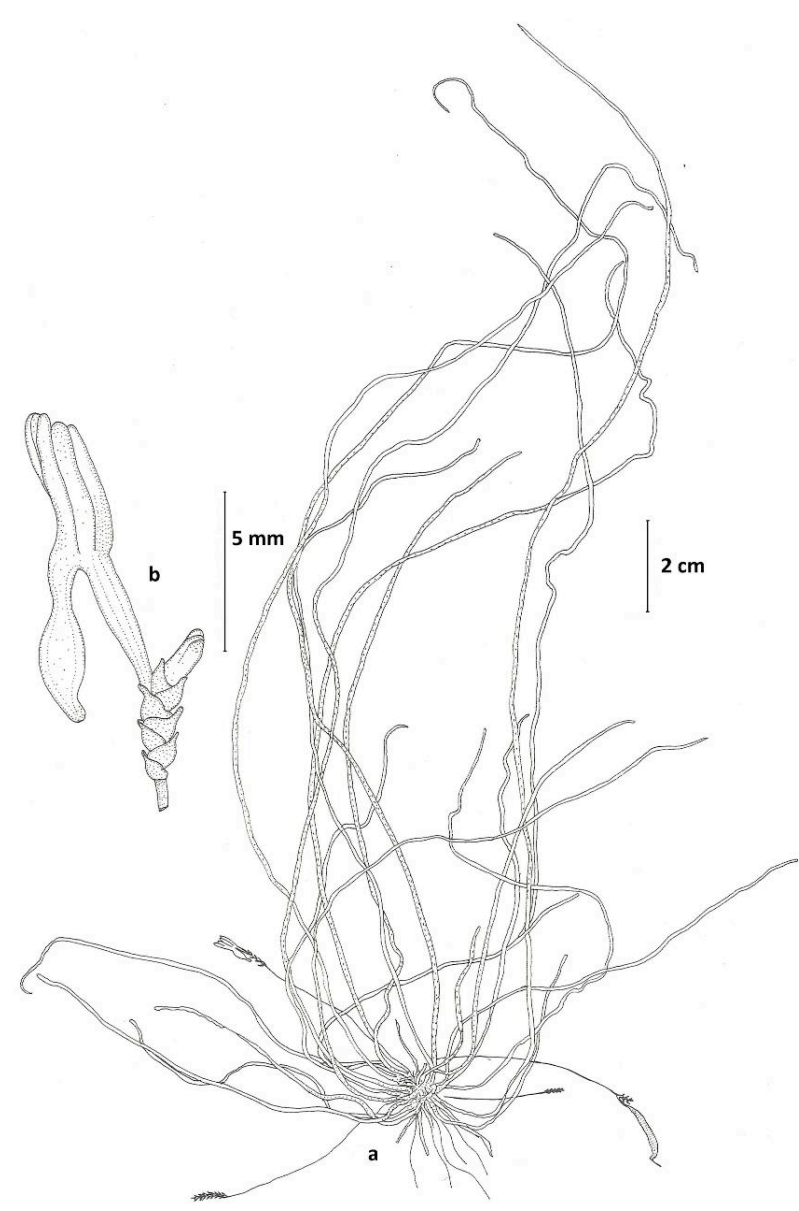

Figure 1. Taeniophyllum filiforme J.J. Sm. a - Habit; b - Flower

ca. $5.5 \mathrm{~cm}$ long, slender. Bracts ca. $1.5 \mathrm{~mm}$ long, membranous. Flowers pale yellow, ca. $1 \times 0.25 \mathrm{~cm}$. Pedicel with ovary ca. 4x1 mm. Dorsal sepal narrowly oblong, ca. 4x1 mm, obtuse at apex. Lateral sepals narrowly oblong, ca. $4 \times 1.5 \mathrm{~mm}$, obtuse at apex. Petals oblong - lanceolate, ca. $4.5 \times 1.5 \mathrm{~mm}$, obtuse at apex. Lip fleshy, ca. $3.8 \times 2.5 \mathrm{~mm}$, pale yellow, sheathing the column; spur club - shaped, c. 4.5 x $1.8 \mathrm{~mm}$. Column ca. $1 \mathrm{~mm}$ long, with a long upwardly facing beak on the operculum.

Specimen examined: 28.vi.2002, inland evergreen forests, Rutland Island, South Andamans, Andaman \& Nicobar Islands, India, coll. K. Karthigeyan, 6086 Port Blair herbarium (PBL) (Image 3).

Flowering \& Fruiting: June-August.

Ecology: Extremely rare; in the inland forests of Rutland Island growing on the tree trunks of Pterocarpus dalbergioides Roxb. ex DC.

Distribution: India (Andaman Islands); Peninsular Malaysia, Thailand and Indonesia.

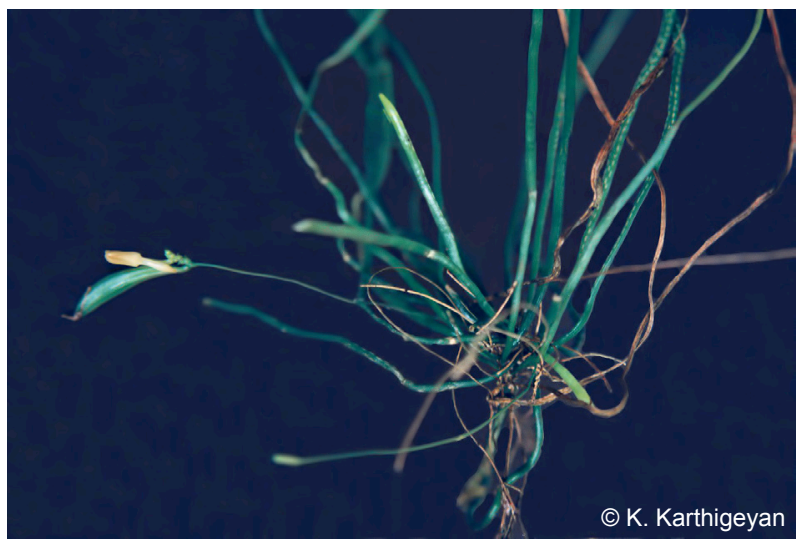

Image 1. Taeniophyllum filiforme habit

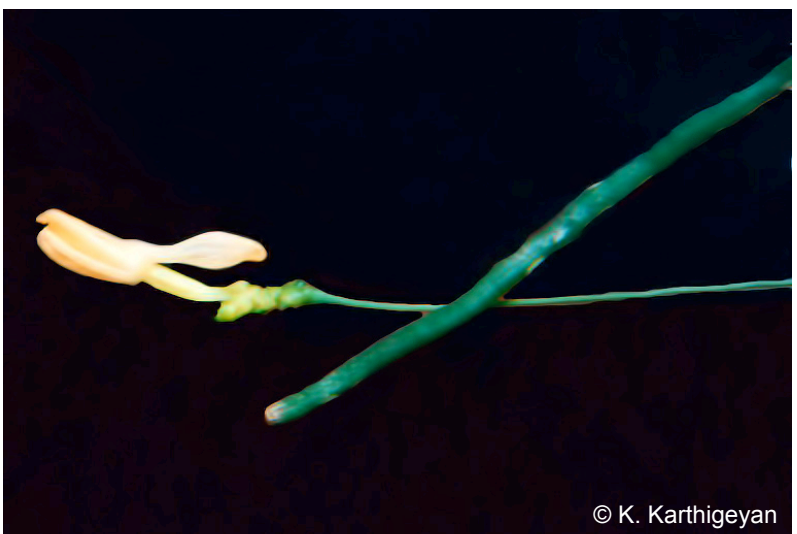

Image 2. Taeniophyllum filiforme close up view of flower

Note: This species can easily escape from sight owing to its small leafless habit, green roots that grow on the tree trunks either near the forest floor or among the dense foliage of smaller twigs. This species is distributed in Peninsular Malaysia, Thailand and Indonesia. In the Andaman Islands only very few individuals were located from a single spot.

\section{REFERENCES}

Comber, J.B. (1990). Orchids of Java. Royal Botanic Gardens, Kew, 360pp.

Comber, J.B. (2001). Orchids of Sumatra. Royal Botanic Gardens, Kew, 980pp.

Kumar, C.S. \& K.S. Manilal (1994). A Catalogue of Indian Orchids. Bishen Singh Mahendra Pal Singh, Dehra Dun, $85 \mathrm{pp}$.

Mabberley, D.J. (2008). Mabberley's Plant-book: A Portable Dictionary of Plants: Utilizing Kubitzki's The Families and Genera of Vascular Plants (1990) and Current Botanical 


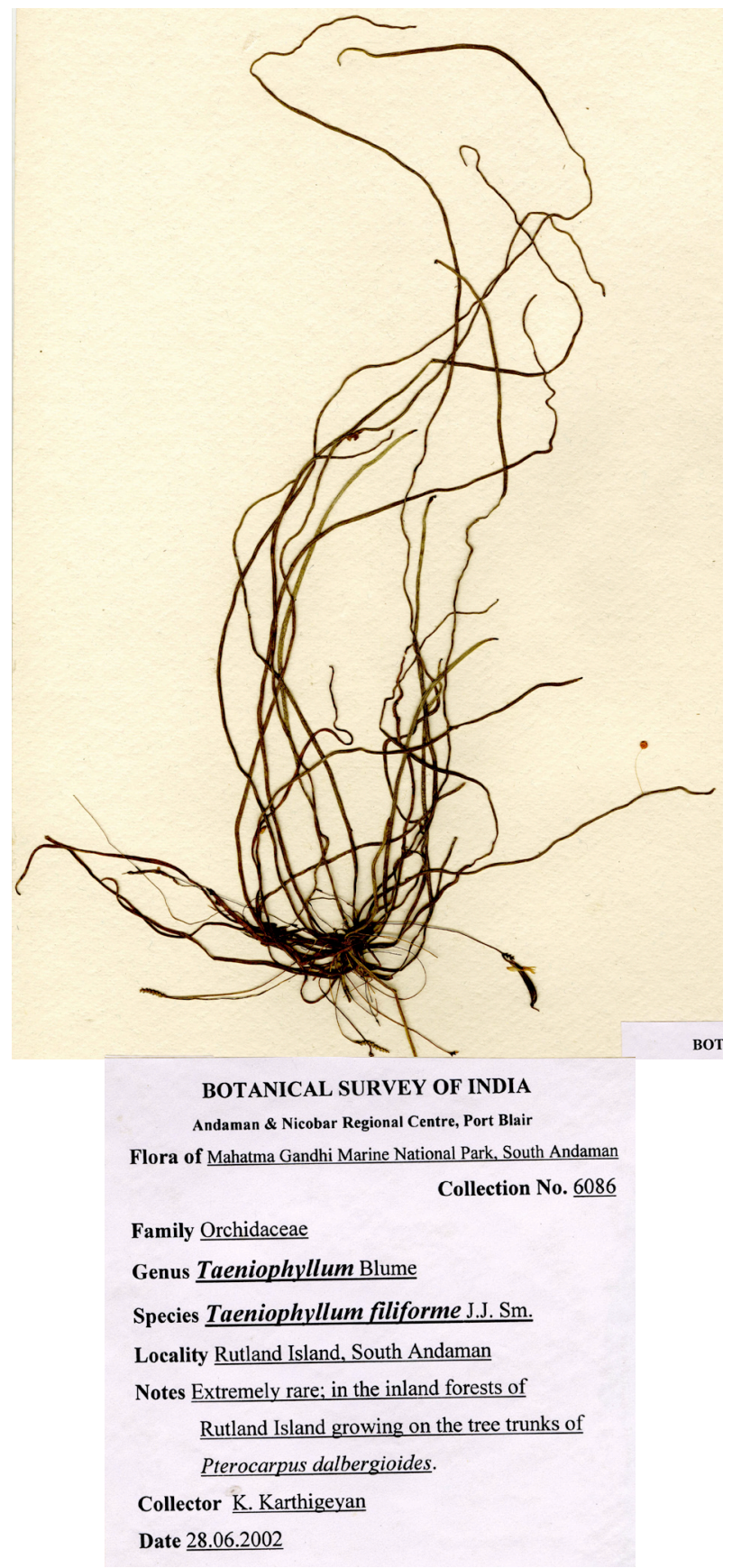

Image 3. Herbarium of Taeniophyllum filiforme
Literature, Arranged According to The Principles of Molecular Systematics - Edition 3. Cambridge University Press, xviii+1021pp.

Mathew, S.P. (1998). A supplementary report on the flora and vegetation of the Bay Islands, India. Journal of Economic and Taxonomic Botany 22(2): 249-272.

Pandey, R.P. \& P.G. Diwakar (2008). An integrated check-list Flora of Andaman and Nicobar Islands, India. Journal of Economic and Taxonomic Botany 32: 403-499.

Rao, M.K.V. (1986). A preliminary report on the angiosperms of Andaman and Nicobar Islands. Journal of Economic and Taxonomic Botany 8: 107-184.

Seidenfaden, G. (1988). Orchid genera in Thailand. XIV. Fifty - Nine Vandoid genera. Opera Botanica 95: 1-398.

Seidenfaden, G. \& J.J. Wood (1992). The Orchids of Peninsular Malaysia and Singapore. Olsen \& Olsen, Fredensborg, 579pp.

UNEP WCMC (2003). Checklist of CITES Species. UNEP World Conservation Monitoring Centre, Cambridge, 1$339 \mathrm{pp}$. 